no whey. However, with relation to the fresh weight or to nitrogen this activity is much lower than that observed for the intestine. There was no difference in mean activity along the first $85 \mathrm{~cm}$ of the intestine between the different groups of animals. On the other hand, the differences in activity observed between individuals and between litters were considerable and could be between $\mathrm{r}$ and ro both with regard to total activity or according to specific activity (expressed to nitrogen).

In pigs where lactase activity was observed throughout the intestine there was a maximum total activity in the mucus along the first third of the small intestine with a subsequent decreasing activity as far as the ileum. In the mucus of the caecum and large intestine, lactase activity was higher in pigs receiving dried whey, however it only represents a small fraction of the total activity for the whole of the intestine : $9.7 \mathrm{p}$. Ioo for pigs receiving $60 \mathrm{p}$. Ioo lactose and r.6 p. Ioo for the control animals. The intestinal contents of pigs receiving whey also showed a higher activity from the third part of the small intestine onwards, the ratio of the total activity in the large intestine between these pigs and the controls is $\mathrm{I}_{4}: \mathrm{I}$.

These results can indicate that, in the pig, more lactose is utilized through microbial fermentation, followed by absorption of the fermentation products, than through intracellular hydrolysis and absorption of glucose and galactose. Several results obtained during in vivo absorption studies confirm this hypothesis.

\title{
INFLUENCE DE LA TEMPÉRATURE D'ACCLIMATATION DE LA TRUITE (“ SALMO GAIRDNERI " RICH.) SUR L'ACTIVITE LIPASIQUE DU TISSU INTERCAECAL
}

\author{
C. LÉGER \\ Station ds recherches de Nutrition, \\ Centre national de Recherches zootechniques, I. N. R. A., \\ 78 - Jouy-en-Josas
}

Le premier stade de la digestion des graisses, qui joue un rôle déterminant dans l'utilisation digestive, étant l'hydrolyse intestinale intraluminaire des triglycérides alimentaires, il nous a paru intéressant de nous attacher à montrer in vitro la présence d'une activité lipasique chez la Truite.

En 1966, Brockerhoff avait mis en évidence, in vivo, l'hydrolyse intestinale intraluminaire des triglycérides alimentaires chez le Poisson, mais n'avait pu démontrer in vitro l'existence d'une activité lipasique dans le tissu intercæcal (tissu adipo-conjonctif entourant les cœecums pyloriques de la Truite). Pourtant, depuis la fin du siècle dernier on savait que la Truite possédait un pancréas dont les cellules étaient diffuses dans ce tissu.

Dans une première étape, nous avons donc recherché et montré (C. LÉGER, P. BERGoT, J. Flanzy, A.-C. François, I97o. C. R. Acad. Sci. Paris, 270, 2813-28I6), grâce à la mise au point d'une méthode originale de préparation, la présence d'une activité lipasique au niveau du tissu intercæcal. L'activité spécifique est de 0,4 unité lipase par milligramme de protéines à $25^{\circ} \mathrm{C}$ et pH 8,o. 
Dans une seconde étape, nous avons comparé certaines propriétés cinétiques de ces extraits enzymatiques provenant de deux séries de lots de truites : pour une série, les truites étaient acclimatées à $10^{\circ} \mathrm{C}$, pour l'autre série à $20^{\circ} \mathrm{C}$. Les extraits enzymatiques des Truites à r $0^{\circ} \mathrm{C}$ présentent un $\mathrm{pH}$ optimum d'activité égal à 8,7 , pour ceux des truites à $20^{\circ} \mathrm{C}$ un $\mathrm{pH}$ optimum de 8,4 , différence de $\mathrm{pH}$ faible mais reproductible sur chaque couple de lots basse-haute température. De même, on trouve une différence importante dans l'allure des courbes d'activation thermique des extraits enzymatiques provenant des truites acclimatées à basse et à haute température.

Ces différences de comportement de l'enzyme, d'ordre qualitatif, suggèrent l'existence de mécanismes adaptatifs. On peut supposer, ou bien que la macromolécule d'enzyme subit un remaniement physico-chimique discret, ou bien que la distribution de deux ou plusieurs espèces moléculaires de la même enzyme est modifiée. Ce sont là des interprétations auxquelles nous sommes habitués pour certaines enzymes endogènes, mais entièrement nouvelles pour les enzymes exogènes de la digestion.

\section{SUMMARY}

\section{INFLUENCE OF THE TEMPERATURE OF ACCI,IMATIZATION ON L,IPASE ACTIVITY OF INTERCAECAI TISSUE IN THE TROUT (“SAIMO GAIRDNERI 》 RICH.)}

Since the first stage in the digestion of fats which plays a decisive role in digestive utilization is the intraluminary hydrolysis of dietary triglycerides, it appeared of interest to attempt to show the presence of lipase activity in the trout in vitro.

BROCKERHOFF demonstrated intraluminary intestinal hydrolysis of dietary triglycerides by the fish in vivo in 1966, but was unable to show any lipase activity in vitro in the intercaecal tissue (adipo-conjunctive tissue surrounding the pyloric caeca of the trout). Nevertheless, since the end of the last century, it has been known that in the pancreas of the trout, the cells are diffused in this tissue.

Firstly, we have been able to show (C. Léger, P. Bergot, J. Flanzy, A.-C. Françors. 197o. C. R. Acad. Sci., Paris, 270, p. 2813-28I6) the presence of lipase activity in the intercaecal tissue, by using an original method of preparation. The specific activity is 0.4 lipase units per milligram of protein at $25^{\circ} \mathrm{C}$ and $\mathrm{pH}$ 8.o.

Secondly, we have compared certain kinetic properties of these enzyme extracts originating from two groups of fish : the trouts in one group were acclimatized at $10^{\circ} \mathrm{C}$ and in the other at $20^{\circ} \mathrm{C}$. The enzyme extracts from the trouts at $1^{\circ} \mathrm{C}$ showed a $\mathrm{pH}$ optimum of 8.7 and those from the trouts at $20^{\circ} \mathrm{C}$ a $\mathrm{pH}$ optimum of 8.4 , a slight difference in $\mathrm{pH}$, but reproductible on each couple of the low-high temperature groups. In addition, there is an important difference between the patterns of the heat activation curves of the enzyme extracts originating from trouts acclimatized at low and high temperatures.

These qualitative differences in the behaviour of the enzyme suggest the existence of adaptative mechanisms. Either the enzyme macromolecule is subjected to a slight physico-chemical change, or the distribution of two or several isoenzymes is modified. These interpretations which are known for certain endogenous digestive enzymes, are entirely new in the case of exogenous enzymes. 